Dor: http://dx.doi.org/10.11157/sites-vol1oissid236

- ARTICLE -

\title{
WAYS OF SEEING: WHAKAPAPA
}

\author{
Mere Roberts
}

\begin{abstract}
The ideas advanced in this paper accept a priori the existence and validity of alternative world views which each seek to make sense of and understand the world. More specifically it advances the theory that matauranga and wananga ${ }^{1}$ comprise a body of knowledge situated within a cognitive genealogical framework called whakapapa; and that this provides the theoretical or epistemological basis for a Maori 'way of knowing' about the world. As will be described, this framework embraces multiple ontologies concerning how things came to be, each of which is grounded in knowledge of natural science (primarily biological) as well as spiritual knowledge. Examples drawn from whakapapa of selected plants and animals not only reveal the extent and nature of the knowledge embedded in matauranga, but also highlight the various functions whakapapa appear to have served in an oral society. These roles, and the potential of whakapapa to continue to contribute to the growth of knowledge are also discussed in the light of perspectives from other scholars of matauranga.
\end{abstract}

\section{INTRODUCTION}

Whakapapa as a philosophical construct implies that all things have an origin (in the form of a primal ancestor from which they are descended), and that ontologically things come into being through the process of descent from an ancestor or ancestors. Further, because there is in Maori cosmogony only one set of primal parents or ancestors (Ranginui and Papatuanuku) from whom all things ultimately trace descent, all things are related.

In its most familiar guise, that of recording human genealogies or 'family trees', whakapapa describe the descent and relationships of only one 'thing' or species; namely humankind (Homo sapiens) which, depending on tribal origins, can be traced back to one or other of the children of Rangi and Papa. 
The whakapapa described in this paper concern the non-human descendants of several of the children of Rangi and Papa often referred to as the 'environmental atua' namely: Tane (ancestor of forest, trees, birds and insects, and in some tribal genealogies, of humans); Tangaroa (of the sea and sea creatures, and in some tribal genealogies, of humans); Rongomatane (of the cultivated foods e.g. kumara, taro, yam); and Haumiatiketike (of the uncultivated or 'wild' foods e.g. aruhe or fernroot). It also draws on previous work by Roberts et al $(2004,2010)$ that describes a number of important functions of this epistemological construct. Of these, the focus here will be on its function as a folk taxonomy and as a 'mind map' of a particular ecosystem containing species valued by Maori.

It would be wrong to conclude from this focus on non-human species and their ecosystems that humans are excluded. Whatever their origins (see above), in all non-human whakapapa humankind is present but 'off stage' in the wings, interacting with their kinsfolk as and when appropriate. This is evidenced in some of the narratives recounted below. Also present on and off stage are the spiritual beings, including the poutiriao in the highest heavens, along with other beings both visible and invisible here on earth, who protect and control the behavior of humans in their interactions with their kinsfolk.

\section{NON-HUMAN WHAKAPAPA}

\section{The Whakapapa of the Kumara}

In order to assist the reader to shift their mindset into this 'way of seeing, we begin with a brief description of a kumara (Ipomea batatas) whakapapa shown in Figure 1 (compiled by Brad Haami, 2009 from Best, 1908, 1977; Miller, 1971; and Hohepa Delamere pers.com.1999). Kumara provide one of the best recorded non-human whakapapa, and have the added advantage of a rich accompanying narrative (from Best, 1977: 825-832) which provides the rationale for the inferred relationships.

It begins with Rongo-maui, the husband of Pani-Tinaku (Tinaku, the germinator) and a younger brother of the star Whanui (Vega). Pani's nephews the Maui brothers taunted Rongo-maui concerning his failure to go fishing and thus provide food for his family. Shamed by this accusation, he decided to ascend to the heavens and ask his tuakana Whanui, guardian of the celestial kumara, for some of his tubers. When Whanui refused, Rongo-maui hid from sight then returned and stole the kumara taking them back to earth in his scrotum. (In so doing, theft entered this world.) 


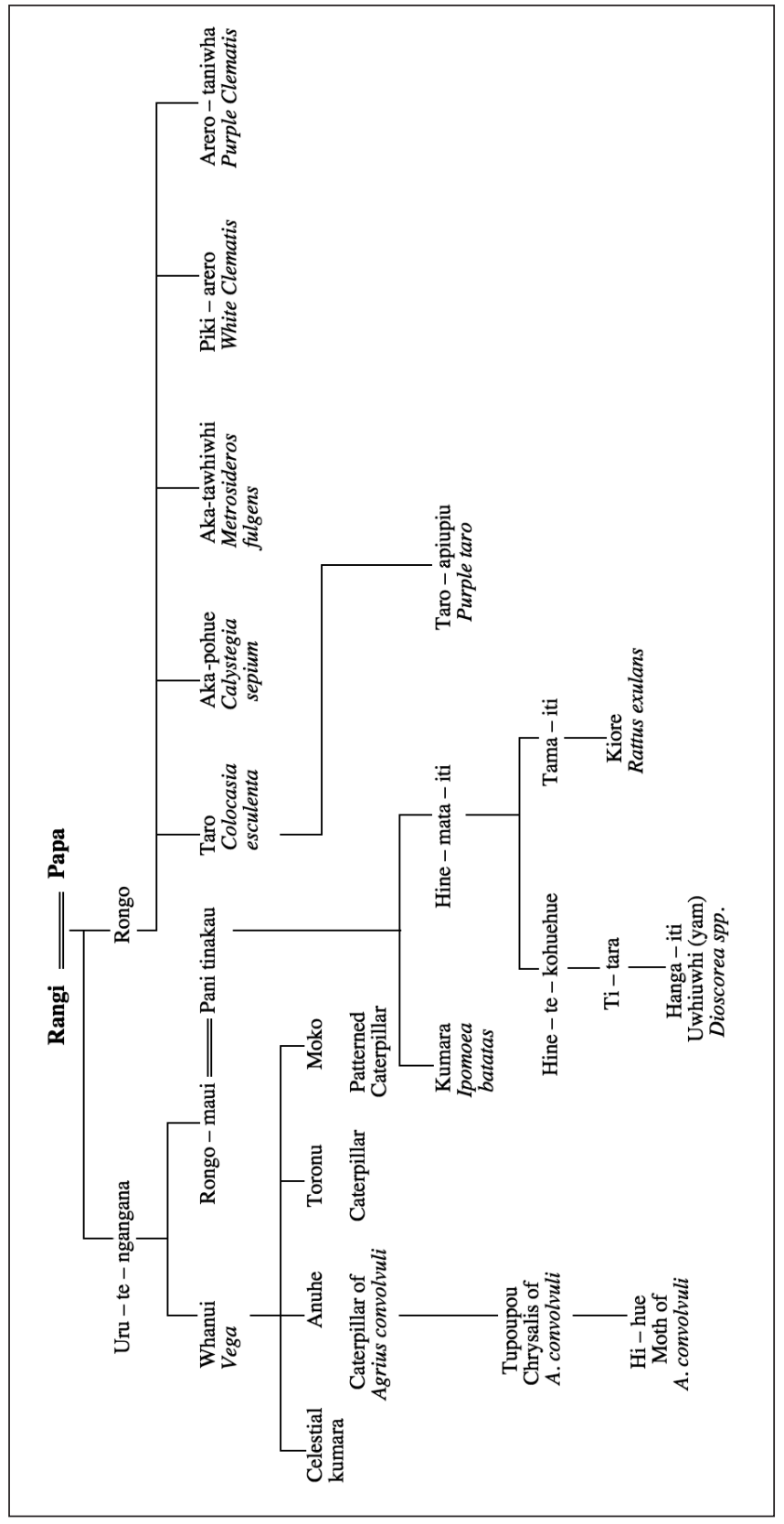

Figure 1. Whakapapa of Rongo 
Rongo-maui then impregnated his wife Pani and told her to go to the waters of Te Wai-o-Monariki and give birth to their offspring. And so Pani gave birth to her children Nehutai, Patea, Waiha, Pio, Matatu, Pauarangi, Toroa-mahoe, Anurangi, and Aka-kura, all of whom became the ancestors of earthly varieties of kumara. Rongo-maui then instructed Pani to cook the tubers so as to free them of the tapu that clung to them on account of their celestial origin (this was the origin of tikanga relating to the removal of tapu by means of cooking food).

Pani's nephews then partook of her kumara before asking how she had obtained them. Pani was silent, so Maui followed her during the night and watched as she gave birth in the waters of Te Wai-o-Monariki. On informing his brothers they were being fed on the impurities of Pani, they departed for foreign lands including Aotearoa (New Zealand). Realizing she had been observed, Pani was so overcome with shame she fled to Mataora (an underworld located in the ancestral homeland Hawaiiki) taking with her their youngest daughter Hine-mata-iti, who became the ancestor of the kiore (native rat). These creatures still follow the ways of Rongo-maui by stealing kumara tubers kept in storage in the rua kumara.

Meanwhile Whanui (who is also the tohu or sign indicating the time for harvesting of the kumara) looked down from the heavens and on seeing men busy attending to their gardens, realised Rongo-maui had stolen some of his children. So he called on Anuhe, Toronu and Moko to descend and attack the crops. These caterpillars continue to do so every summer on damp nights, as punishment for the theft by Rongo-maui. (In addition to the theft of a food intended only for the atua, Whanui's anger may also have been fueled by the transgression of the tuakana/teina relationship.)

Another account (Anderson, 2000:2) adds a further dimension to this whakapapa by including other atua, each of whom provide particular physical attributes to the kumara, and to whom rituals of propitiation were performed to ensure ongoing protection. These include four sons of Rongo-ma-tane: Ihenga- the personification of that part of the plant given as an offering of the first fruits to the gods; Rakiora- who imparts fertility and abundance and protects the crops when stored; Pahaka- deity of the crops in storage; and Matiti- guardian of the door of the storehouse.

Points important to this paper which emerge from these accounts are as follows: 
- Maori knowledge concerning the origin and relationships of material things such as the kumara is visualized as a network of time-space coordinates arranged upon a genealogical framework called whakapapa. The past (personified as ancestors) is still present and continues to impact on events today; so that each planting and harvest of the kumara is a reenactment of the circumstances surrounding its origins;

- Relationships extend beyond the biological to material objects such as stars, as well as spiritual and historical things which are all perceived as somehow related in space-time;

- Empirically based biological knowledge (e.g. of the kumara life cycle including its pests, predators, and environmental indicators) are encoded in the whakapapa;

- Taxonomic groupings based on utility, morphology, habitat and cultural beliefs are included along with their perceived ancestral origins and ontology;

- The accompanying narrative provides explanatory theories as to how things came to be, as well as serving as a parable that contains moral guidelines concerning tikanga (correct and incorrect conduct).

- Collectively, all of the above provides a 'cosmoscape' of a particular place, or habitat; in this sense non-human whakapapa act as a mental 'mind map' of a specific ecosystem.

Whakapapa of Lizards and Tuatara

The whakapapa illustrated below (Figures $2 \& 3$ ) further demonstrate two functions of whakapapa as outlined above; namely as a genealogically based folk taxonomy, and as an ecosystem map.

Taxonomically, all species of skinks and geckos along with the tuatara are commonly referred to as reptiles or lizards. Two species in particular, the moko kakariki (green gecko Naultinus elegans) and the tuatara (Sphenodon guntheri and S. punctata) were and still are regarded with dread and fear by Maori for reasons that may have their roots in beliefs concerning crocodiles among the peoples of South-East Asia (Roberts, 2012a) from whence the ancestors of the Polynesians are said to have originated (Howe 2008).

As illustrated in Figure 2 (from Anderson, 200o:159-160) the word 'moko', a Polynesian cognate, was applied by Maori to all our endemic skinks and geckos. In this whakapapa the ancestral origin of moko is perceived as originating from the marine realm (Tangaroa) and not from the terrestrial realm of Tane. 


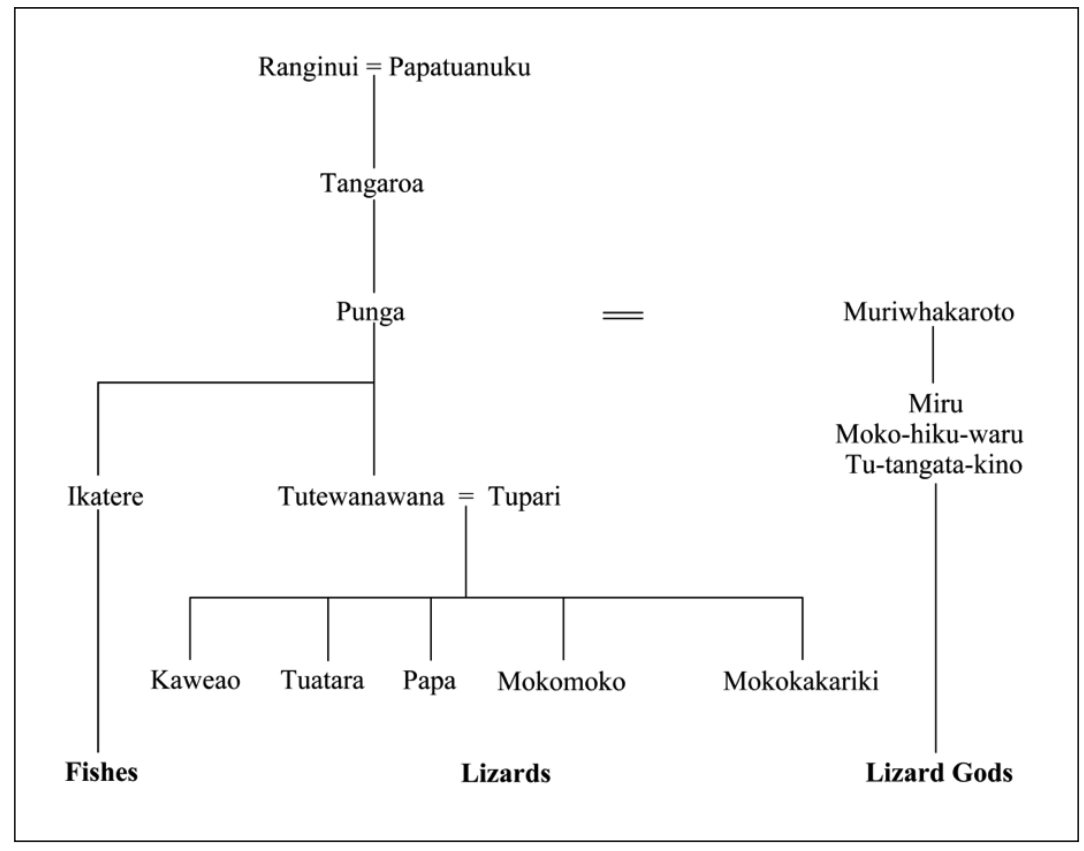

Figure 2. A whakapapa of lizards.

Biological evidence for marine origins is seen in morphological features such as scales and the sinuous locomotion found in both fishes and reptiles. Culturally, both are also perceived as 'ugly' and therefore share a common ancestry from Punga, the atua and personification of ugly things.

Knowledge of ecosystems (e.g. fishes inhabit the sea, lizards the land) is also recognized, resulting in an ontological disjunction between the two groups, the explanation for which is provided in an accompanying narrative. Originally tuatara and shark were brothers, the children of Punga, and inhabited the sea until Tuatara, the elder brother, went ashore to rest on a rock. When his brother called upon him to return to the sea lest he be cooked and eaten by humans, Tuatara refused, saying he would stay on shore where his frightening appearance and the protection of the god Tu would save him from human predation (Reed, 1963:398-399).

Moko are also regarded as representatives of malevolent lizard gods as shown in the third ontological descent line in Figure 2 which depicts their spiritual ancestry and relationships. Both Mokohikuwaru (the eight-tailed lizard) and 
Tutangatakino (the personification of evil humans) are guardians of the house of Miru, who cohabits in the underworld with Whiro, the god of evil (Orbell 1995:120, 233) and if called upon can manifest as the aria (incarnation) of moko.

In contrast to the above whakapapa, the one shown in Figure 3 (from Best, 1982: 269-271 traces the origin and descent of lizards from a different environmental atua: namely Tane, guardian of a terrestrial realm. His wife Hinetupari-maunga is the personification of mountains, and their three children are ancestors of various kinds of rocks. Two of their children (Putoto and Tuamatua) are the source of igneous rocks while their sister Para- whenuamea (personification of the waters of the earth) causes the erosion which gives rise to sedimentary rock. These three ancestors personify habitats within which reptiles (mokopeke) are typically found, i.e. among and beneath rocks and stones, in caves and by rivers and streams. It is also here that taniwha and tipua lurk, sometimes dwelling in deep pools or caves (Best, 1982:474).

Moko-roa (long lizard) or moko-nui (large lizard) were words used to describe lizard-like monsters, also referred to as taniwha (Best, 1982:475). Early explorers to Aotearoa recorded stories of alligator-like monsters or taniwha said to seize and devour men, and to have accompanied several founding canoes from

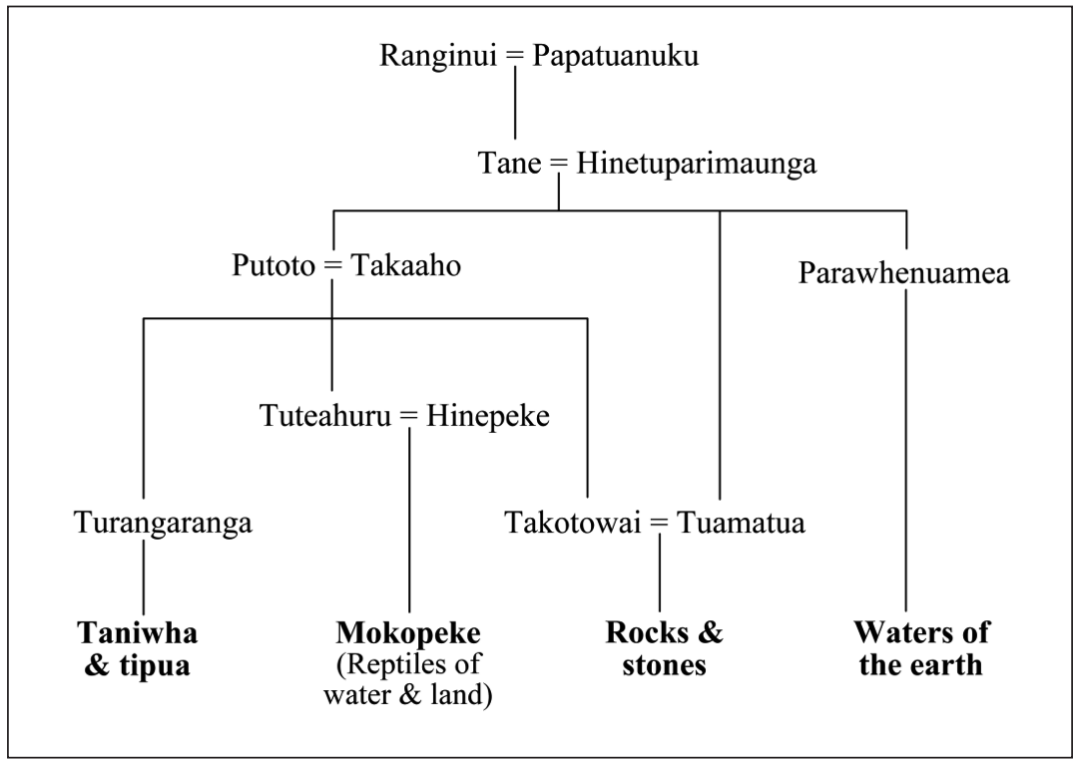

Figure 3. A whakapapa of lizards 
Hawaiki to Aotearoa, often taking the form of whales. Once here many took up residence in caves, rock shelters, or river and ocean dens which because of the dangers (both physical and spiritual) associated with such places, were subject to the restrictions of tapu. This also explains their relationship to lizards as shown in this whakapapa.

Both whakapapa also display empirical knowledge of the biology, ecosystems and behaviors of the creatures they describe, and which provides an important basis for the ordering and relationships in each. For these reasons it follows that Figure 2 privileges the marine origins and fresh water habitats of lizards (hence Tangaroa is the ancestor) while Figure 3 privileges terrestrial origins and habitat (hence Tane is the ancestor).

As noted by Salmond and Salmond (2010:303), 'the possibility of multiple ontologies' occurs when 'different kinds of evidence and explanatory frameworks'are privileged even within common philosophical territory. This 'ontological alterity' or 'cognitive variation' (2010:309) has previously been noted by Salmond (1982:83) in reference to human whakapapa where '[e]ach descent group held a rather different set of ancestral accounts'. Truth claims are then best described as 'contextual truth', tied to 'situational factors'. This stands in contrast to western approaches to 'truth' as objectified and independent of the observer. Knowledge for Maori, Salmond (1982: 85) claims, results from an 'interpretative, dialogical' approach and 'the environment has a right of reply and one is vulnerable to its rebuttals. This plurality of ontologies evidenced in the above is expanded upon in the two whakapapa described below.

\section{A Whakapapa of Haumia-tike-tike (Haumia)}

Further emphasis on the role of non-human whakapapa as maps of ecosystems is shown in Figure 4. This and the one shown in Figure 5 were compiled by Brad Haami for the Maori Natural History gallery display at the Auckland Museum. These composite whakapapa also provide examples of the capacity for different interpretations of the origins and ontology of a thing or things.

Haumia comprises the terrestrial realm of 'wild foods' gathered and eaten by Maori. In winter when cultivated foods such as kumara were in short supplyor too far south to be grown - the root (rhizome) of the bracken fern (aruhe) and that of the ti kouka (cabbage tree) comprised the staple diet. Winter was also the time for warfare and hence according to one account, aruhe was one of the children of Tumatauenga, god of war (Riley, 1997:391). Yet another account says aruhe is the offspring of Pukupuku-te-rangi, ('lumps from the sky') 
SITES: New Series • Vol 10 No $1 \cdot 2013$

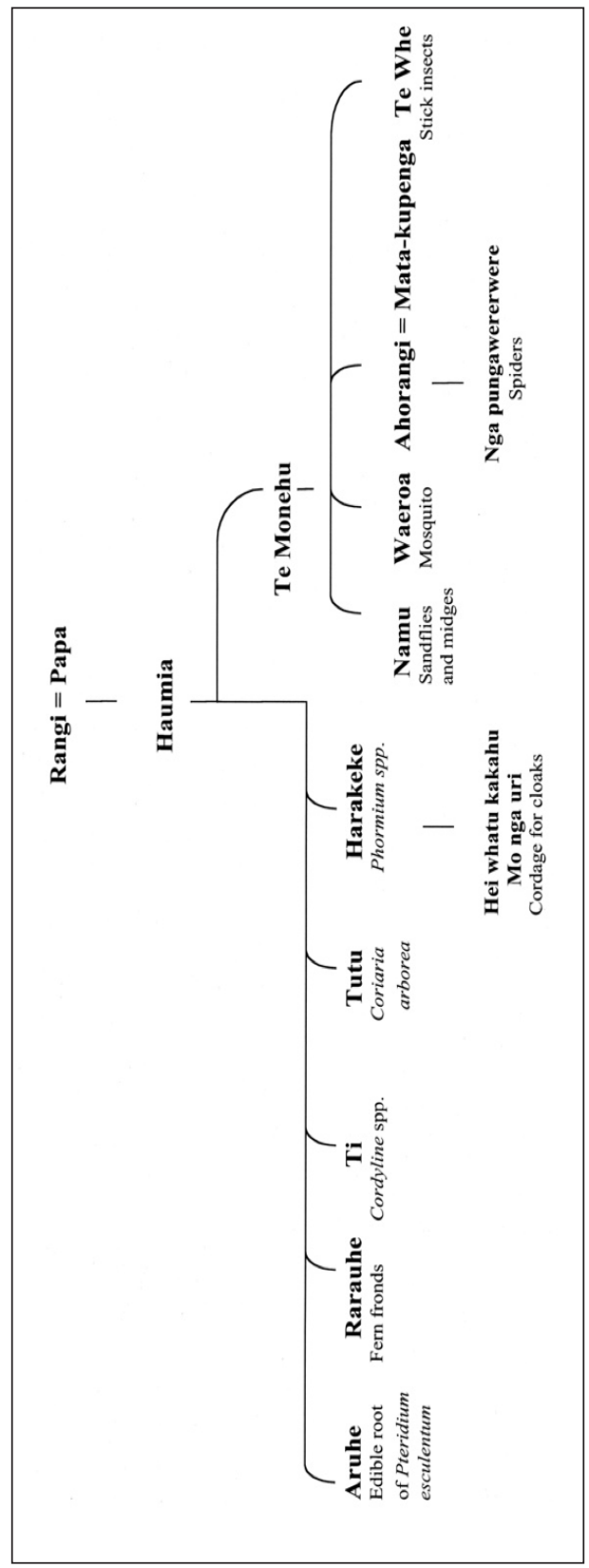

Figure 4. Whakapapa of Haumia-tike-tike (Haumia) 
or Tane-pukupuku-rangi, and grew on the back of Rangi until he was thrust skyward by Tane, causing the roots to fall to the earth (Best, 1977:75).

More generally, however, aruhe is personified as Haumia, from whom it also is said to have originated (1977:73-75) as the following narrative explains. During the battle of the brothers which followed the separation of Rangi and Papa, Tawhirimatea attacked Haumia who (along with Rongo, the personification of the kumara) tried to hide in the ground. Unfortunately the hair of Haumia (the fronds or rarauhe of the bracken fern) protruded above ground, enabling him to be found, dug up and eaten by Tu, the ancestor of humans (Orbell, 1995:49).

Ti, the other staple 'wild food' is also included here as a descendent of Haumia. But in a detailed account provided by Hohepa Delamare (pers.comm.) of which an abbreviated version is published in Simpson (2000:115-123), the ancestors of ti include - in addition to Haumia - two other children of Rangi and Papa, namely Uru-te-ngangana and Rehua. From each of these three atua are derived the various characteristics and unique properties of the ti plant, Haumia being responsible only for its food and medicinal properties.

Tutu's relationship to the aruhe and hence inclusion in Haumia's realm is likely based on cultural grounds as well as habitat as both are commonly found on disturbed or recently cleared land. Juice from the berries of tutu was also used to sweeten the beaten and baked fern root, and to counter the latter's tendency to cause constipation. While none of these three species bear any close morphological resemblance to each other: the rationale for this grouping appears to be their utility or importance as a 'wild food' as well as their habitat relationships.

Also included in Haumia's whakapapa is a lineage descended from Te Monehu, an ancestor who represents the fern fronds. More specifically his name is given to the rust-coloured dust (spores) found on the undersides of the fronds and from which the various species of insects that live among bracken fern are said to be descended (Miller, 1952:5-6). Anyone who has walked through dense bracken fern will be familiar with the clouds of tiny insects that arise like dust into the air when disturbed. Among these, the sandflies and mosquitos are said to be continually waging war against the (human) children of Tu who pull up and eat the aruhe (Best, 1977:73), although other explanations are also given for their attacks on human kind (Best, 1982:580).

Most noticeable on bracken in early mornings when the dew is on the silken threads and reflected by the sun's rays, are the shiny white spider webs, 
wrapped like shrouds around the fronds and containing thousands of baby spiders (nga pungawerewere). These offspring of Ahirangi and Mata-Kupenga (she of the net-like or web-like face), are placed in a separate lineage from insects, a distinction based perhaps on the observation that spiders have eight legs and not six like insects. [Modern scientific classifications also distinguish spiders (arachnids) from insects for similar morphological reasons.] As Miller (1952:4) notes, there are other whakapapa of insects whose lineages and groupings (taxon) also appear to be based on habitat whereby forest insects are perceived as descendents of Tane; or on morphology whereby 'ugly' insects such as centipedes and spiders are perceived as descendents of Punga, the atua of ugly things. One interpretation of 'nga pungawerewere' might therefore be 'the ugly offspring suspended (werewere) by threads'. Alternatively, if 'pu' means 'cluster' this might refer to the 'suspended clusters' of spiders.

\section{A Whakapapa of Tangaroa}

Figure 5, a composite of several whakapapa provided by Brad Haami (2009) for the Natural History gallery at the Auckland Museum further demonstrates the environmental knowledge acquired by Maori concerning important marine resources. What is provided here by way of explanation for the lineages and groupings has been gleaned from both traditional and modern scientific knowledge of these species.

Figure 5 includes Rehua (the star Antares) in addition to Tangaroa as another ancestor of fishes. These two major descent lines (sometimes called whakaheke) are discussed in turn. Rehua signals the heat of summer and is responsible for the ripening of tree fruits (Best, 1982:320) as well as the origin of certain fruit-eating birds (1982:265). The fruits of Karaka, depicted here as an offspring of Rehua, were an important food for Maori and it is likely that the ripening of karaka fruits acts an environmental indicator of the time to fish for Rehua's other children Moki, Maomao and Kohikohi (three species which are commonly found together (Doak, 2003:80). Te Whanau a Apanui (an east coast tribe) say their ancestor Pou brought the moki with him from Hawaiiki to Aotearoa and that the time to fish for this species is when the fruits of Karaka were ripe (Tawhai pers.comm). Hapuku is another descendent of Rehua (Delamare pers. comm.) and an important source of food for Maori. He is also the ancestor of the tree ferns or 'ponga' including Mamaku (Cyathea medullaris), Te Poka (C. dealbata) and Katote (C. smithii). Their fish origins are explained in the story of Tawhaki who whilst on earth attacked the offspring of Hapuku. Some survivors fled to the sea where they became whales and other great fish, while others fled to the forests where they became the 'fish of the forest' (White, 


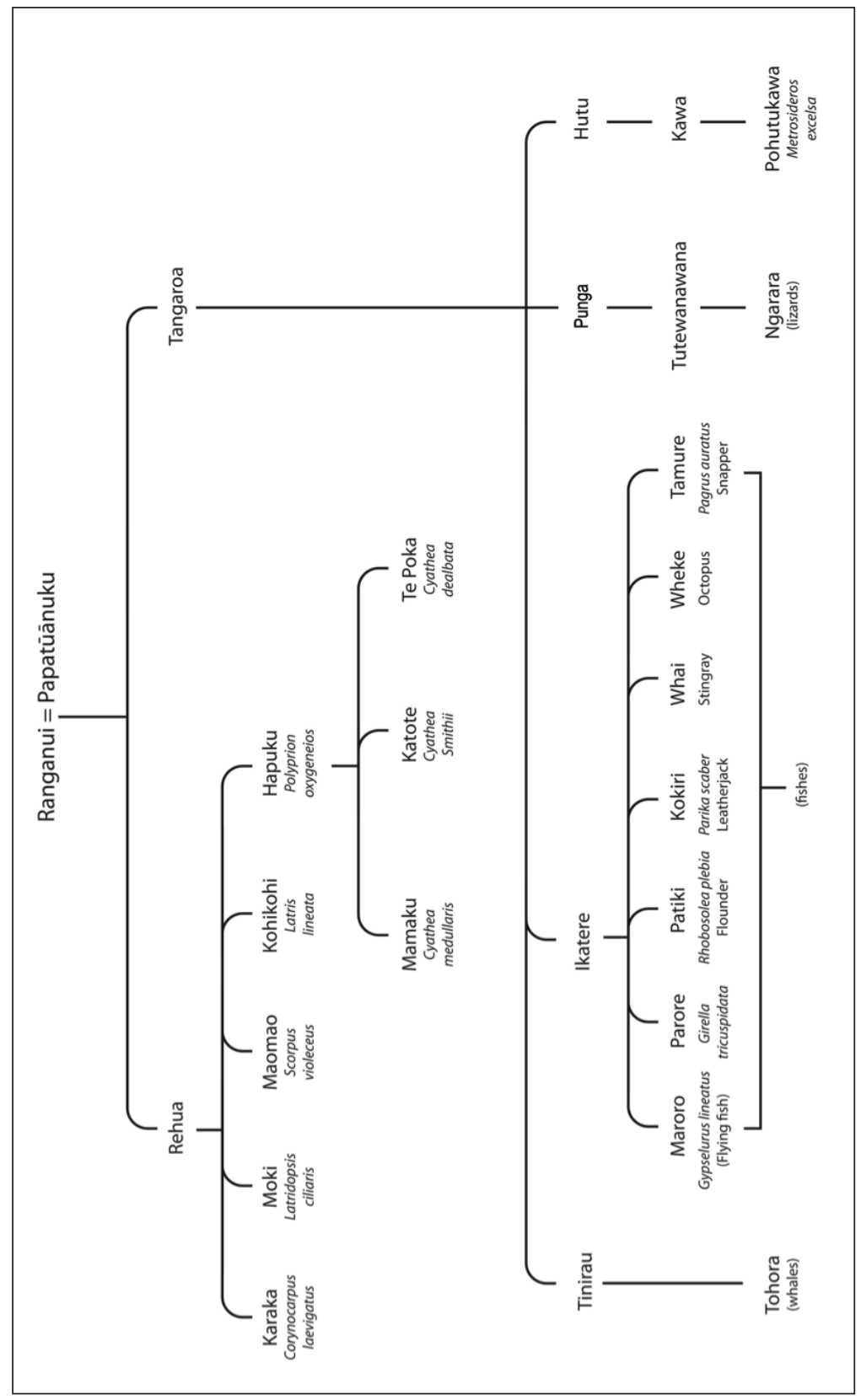

Figure 5. A Whakapapa of Tangaroa 
1887:59), more commonly known as 'tree ferns'. It is said that vestiges of this marine ancestry can still be seen today in the large scale-like depressions on their trunks left by fallen fronds.

The other major descent line is that from Tangaroa, commonly regarded as the guardian of the marine realm, and his son Ikatere, the ancestor of fishes. One narrative concerning the origin of various fish species involves Ruatepupuke whose son transgressed the kawa relating to fishing. As punishment Tangaroa turned him into a tekoteko (gable of a house) located beneath the sea. $\mathrm{Ru}$ atepupuke responded by setting fire to the house, and as people came rushing out he swung at them with his patu. Maroro (flying fish) was too fast and escaped; Whaitere (stingray) suffered a squashed nose; Patiki (flounder) was hit in the eye and ever after both eyes are on one side of his head; Wheketoro (octopus) was struck so hard his tentacles hung down; Kokiri (leather jacket) escaped harm but Tamure (snapper) was burnt on the head, hence his red colouration (Mead, 1986:8-11). Some of these fish are important not only as food but also in mythology: for example the wheke is the pet cuttlefish of Muturangi, who snatched (and still snatches) the bait off Kupe's fish hooks, while whai or stingray are known in some areas as kaitiaki and /or taniwha. Another son of Tangaroa is Punga (the personification of ugly things), whose son Tutewanawana (sometimes called Tutewehiwehi) gives rise to reptiles or lizards that later fled to the land (see Fig. 2 and its accompanying narrative). In other whakapapa of Tangaroa sharks, personified or represented as 'Mango' (Best, 1982:568) are also said to be the progeny of Punga, while his brother Karihi gave rise to other 'repulsive' offspring, among them certain fish (frostfish, barracuda, conger eel and freshwater eel), along with lizards and insects (Best, 1982: $261 ; 433$ ). In this account Punga is descended from Whaitiri (the thunder maid) and Kaitangata (the man-eater) and their offspring Hema (1982:421). Yet other accounts state that Takaaho, one of the children of Rangi and Papa (Best, 1995:75) was the progenitor of sharks. His name might be translated as 'taka' (to roam at large, range free) and 'aho' (a fish; he ariki taniwha) (Williams, 2003).

Whale origins are also included in Figure 5 and follow Polynesian traditions in which they are said to be descendants of Tinirau, the son of Tangaroa (Best, 1995:180). A Rarotongan tradition gives the name of the fishpond source of whales as Nga Tama ika a Tinirau (Walter and Moeka'a, 2000). Tinirau (whose name means countless myriads of fish ${ }^{1}$ ) is the guardian of Te Puna-a-Tinirau, sometimes synonymous with Te Puna-i-Rangiriri, the sacred pool at Hawaiki from whence all fishes arose. This pool is also said to be the origin of whales (Best, 1924:183). Other accounts say that whales along with porpoises come from the union between Te Puwhakahara and Hine-parauri, or between Te 
Puwhakahara and Rehuroa (Best, 1982:260). Whales are also said to be represented by Takaaho, an offspring of Tangaroa (Best, 1995:181); or by Rongamaitahanui (Best, 1982:318). While these various accounts indicate that whales like sharks can have multiple ontologies, they all agree on the demarcation of these lineages from those of the fishes. Use of stranded whales as a source of meat and bone no doubt enabled Maori to become familiar with their anatomy including differences between fishes (with gills) and mammals (with lungs) despite both cohabiting the same (marine) habitat.

Another offspring of Tangaroa shown in Figure 5 is that of Hutu, an ancestor who descended to the underworld to retrieve his wife and became entangled in the roots of trees growing down from the upper world (Riley, 1994:156). Other stories talk of the pathway taken by the spirits of the deceased to the Rarohenga or Reinga (underworld) which in northern traditions is at te RerengaWairua. Here the spirits cling to the roots of a pohutukawa tree in their descent. Similarly in the Bay of Plenty the spirit descends by means of a root or vine into the sea and thence to the underworld (Best, 1982:85). As these accounts describe, this tree (and the assumption is that it is most likely to be the pohutukawa) spans the interface of Tane and Tangaroa while in certain sacred places its roots reach deep into the underworld beneath the sea. Together these physical and spiritual attributes provide a rationale for the inclusion of this tree in Tangaroa rather than in Tane. The close habitat association between kawakawa trees (represented by Kawa) which typically grow beneath and act as kaitiaki or guardians of seedling pohutukawa, also explains their inclusion here (Delamare pers. comm.)

\section{DISCUSSION}

Whakapapa As Folk Taxonomies And Ecosystem Maps

According to Salmond (1991:42) 'whakapapa (genealogy) was the central principle that ordered the universe', a view shared by Tau (1999:13) who says 'for Māori, the world was ordered and understood by whakapapa' and is 'the skeletal structure to Maori epistemology' (1999:15). Both affirm the role of whakapapa as fundamental to a Maori way of knowing. In this account of the whakapapa of some plants, animals and other environmental phenomena of importance to Maori, we seek to further demonstrate several different functional aspects - namely that of a kinship based taxonomy and as an ecosystem map - for this epistemological construct.

As understood here, whakapapa act as a genealogical framework upon which 
knowledge is situated; i.e. it is not of itself 'knowledge,' but the repository of information about the world. Names provide additional information, and when organized (classified) into lineages vertically and horizontally, the narrative(s) then add 'flesh' (knowledge) to the 'bones' of this skeletal framework. Knowledge and whakapapa are interdependent parts of a whole; which in its entirety comprises both matauranga and wananga - everyday and esoteric knowledge respectively (Williams 2001). Knowledge itself has a whakapapa which like all other things on earth originates in the celestial realms. In the creation chant of Te Kohuwai (retold in Salmond, 1991:39-40) it emerges at the very beginnings of a long genealogical sequence telling of the origins of the cosmos. (Later on a demi god [Tane] climbs up to the heavens to retrieve this knowledge contained in three baskets). These genealogies are not chronological as in human whakapapa, but sit within a collapsed space-time framework. Ancestral events (such as the punishment by Whanui for theft of the kumara) may therefore be repeatedly re-enacted as for example, by the annual recurrence of the insect pests of the kumara. In other words, the past is ever present, carrying with it implications for the future.

Of the several roles or functions suggested for whakapapa and discussed in detail elsewhere (Roberts et al 2004; 2012) this paper has placed emphasis on its utility as a 'folk taxonomy' or ethnobiological system of classification. Research among various indigenous peoples highlights their ability to identify and name extensive lists of animals and plants in their area. What is notable about these lists is that with few exceptions, each name matches with scientifically described species. Differing theories have been proposed to explain why and how this capacity has developed. Bulmer's (1974) work among the Kalam in Papua New Guinea included the observation that language used in the construction of these taxonomies was of kinship and descent; also that cultural cosmology is an important aspect in understanding their rationale (Bulmer 1970).

Diamond (1972) suggested that the motivation to name and classify is purely utilitarian while Levi-Strauss (1966) argued that it is not driven by practical needs but the intellectual demand to impose and create order in the natural world. Others (e.g. Berlin, 1992: 8-9) have argued that all classificatory systems reveal the propensity of human beings to discern patterns already inherent in nature. This innate ability to recognize and categorize groups of things that are similar to or different from one another, is he says based primarily on their morphology and phenotypic variation. These groups (taxa) of 'species equivalents' are further grouped into more inclusive taxa arranged in a hierarchy which bear resemblance to those of biological classification of which the 
Domain or Kingdom is the highest and most inclusive category. In western scientific (i.e. biological) taxonomies this quest ultimately leads back in time to an ancestor in one of six 'kingdoms' of organisms (namely Plants, Animals, Fungi, Protists, Eubacteria or Archaebacteria). Among iwi Maori the ancestors are usually identified as one or more of the children of Rangi and Papa, such as those described above.

Interestingly both systems employ genealogy as the underlying template for classification and as the basis for identifying the relationships between and among things. But western scientific descent lines and relationships (phylogenies) are based on assumptions concerning the degree of shared genetic inheritance from a common ancestor, which frequently over-rules or contradicts apparent similarities in habitat, morphology and behaviour. In contrast these three aspects appear to be of primary importance in the lineages and groupings of non-human whakapapa.

Another difference is that western scientific taxonomies restrict an organism's phylogeny to a single lineage and ancestral kingdom while whakapapa allow an organism or group of organisms to claim descent from multiple ancestors, each of which has equal ontological validity.

For example, lizards may trace descent from Tangaroa (Figure 2), or from Tane (Figure 3). These multiple ontologies appear to reflect the emphasis placed on a particular aspect of that organism's biology, behavior, or cultural importance. In Figure 2 the focus (and accompanying narrative) is on the relationships of lizards with fishes and their spiritual guardians, while in Figure 3, the relationship between taniwha and lizards is emphasized. This multifaceted flexibility is best illustrated in a whakapapa of the ti kouka (published in Simpson 2000). Despite being an abbreviated version it is perhaps the most detailed non-human whakapapa that has been published to date. It was given to Simpson (a plant scientist) by Hohepa Delamere, a tohunga from Te Whanau a Apanui, during a series of hui in which both shared their different knowledge and understandings of this plant. In his remarkably detailed account of the anatomy of ti, Delamare described each morphological, physiological or biochemical aspect exhibited by this plant. These traits or momo (interpreted by Simpson as analogous to a gene) were he said, bequeathed by and remained under the continuous control of spiritual ancestors. Three of the most important in this whakapapa are Uru-te-ngangana; Rehua and Haumia. According to Delamere, all whakapapa have such detailed and multiple ontologies, but it was usual to cite only one particular aspect of relevance to the circumstances at that time and place of telling. In the case of ti, the Haumia lineage (whakaheke) concern- 
ing food and medicine was best known and used.

Place based information from the environment as observed and experienced was incorporated into the framework and contributed to a whakapapa's plurality. One would therefore expect that whakapapa will vary from region to region in terms of their cultural and environmentally based content. This may account for the many different whakapapa and or whakaheke of a single organism recorded by Best (1982) and which provide the basis for those illustrated here. But as his informants are seldom named, it is unclear whether these differences represent different tribal accounts; variations in the 'telling' by an individual according to context; or are one of several whakapapa/whakaheke relating to a species each of which encodes different aspects of its biology, behaviour, and/or relationships with humans.

One other aspect of all non-human whakapapa only briefly noted here is the importance of names in coding information relevant to the groupings and relationships. Sometimes the meaning is literal e.g. 'Ika tere' (swimming fish). But many - if not most - names are of ancestors (e.g. Rehua) and/or personifications (e.g. Punga) concerning which there are many layers of meaning both cosmogonical and environmental. As Best (1902:103) noted:

The Maori mind was ever richly stored with ideas of a metaphysical nature; it teemed with personifications and metaphor. His language abounded in emblematical expressions and quaint Old-World conceits. Hence we always see in the primitive myths of the Maori a desire to locate the causality of things, to explain the origin of matter.

Despite the loss of some of the meanings sufficient knowledge remains to conclude that names clearly act as 'word fossils', within which are buried layers of information, the understanding of which requires an in-depth knowledge of cosmogony, the environment and species biology. It is hoped that more research on these aspects will reveal even deeper layers of meaning in nonhuman whakapapa.

Whakapapa: An Open or Closed Knowledge System? A Window on or Mirror of the World?

Experiential learning based on accurate observation, trial and error experimentation and best practice (tikanga) over time has provided iwi Maori with a compendium of knowledge much of which has been recorded both orally and in written form, within whakapapa, as well as in narratives, waiata, whakataua- 
ki and whakairo. Elsewhere Roberts (1998) has commented on the similarities between experiential knowledge (especially the traditional ecological knowledge of all indigenous peoples) and western science. This knowledge (both practical and theoretical) would once have been labeled by western scholars as 'natural history' or 'natural philosophy.' Today depending on the whakapapa in question, disciplines such as biology, ecology, or any other branch of the natural sciences e.g. geology or astronomy provide an appropriate analogy. But to equate this body of knowledge with western science is to do it a disservice. Both matauranga and wananga encompass much more than scientific knowledge of the world, by seeking to provide spiritual and moral in addition to material explanations for why and how things came to be. This results in a subjective, 'values-based science' specific to place and to culture and hence distinct from that of western science. As Marsden (1975:191) puts it:

The route to Maoritanga through abstract interpretation is a dead end. The way can only lie through a passionate, subjective approach....the charge of lacking objectivity does not concern me: the so-called objectivity some insist on is simply a form of arid abstraction, a model or a map. It is not the same thing as a taste of reality.

This intimacy or 'knowing by acquaintance' has been commented on by Gillett (2009). He also observes that Maori understandings of the world as expressed in non-human whakapapa reveal subjective engagement in the world rather than an objective 'looking at' the world. He therefore suggests a connection between the relational, open and multilayered ontologies found in non-human whakapapa such as that of the kumara, and Heidegger's metaphysics. In rejecting Cartesian objectivity and its separation between the observer (a thinking self) and the outside world, Heidegger posits a type of 'knowing by acquaintance' that he calls 'circumspection.' The engaged nature of circumspection establishes a kind of connectedness between self and the world such that neither can be understood without reference to the whole (Gillett 2009). In this philosophy knowledge is embedded and situated, whereby truth is viewed as a multi-layered 'un-concealing' of things, a view which resonates with Maori constructions of knowledge in that metaphor, personification and narrative when used to construct whakapapa reveal and conceal many layers of meaning (Roberts and Wills, 1998).

This Heideggerian view of Maori philosophy also resonates with what has elsewhere been called 'situated knowledge.' According to Howitt and SuchetPearson (2006:332), indigenous knowledges are situated in a way that means 'any understandings and interactions are based on contextualized and relevant 
knowledges and terms of reference. This is in contrast to the claim of Eurocentric knowledge to be universal. Critics argue that this claim constructs a circular argument of self-legitimization in which the Eurocentric self'sets itself within a hall of mirrors; it mistakes its reflection for the world' (Rose, 1999 quoted in Howitt and Suchet-Pearson, 2006:326).

But in a stimulating critique of Maori epistemology, Tau (2001:136) argues that Maori are guilty of this same sin. While reaffirming the central importance of whakapapa, he also says that it imposes a closed system of beliefs whose function is to maintain an established order. In his words:

These beliefs were held together by whakapapa, which functioned to maintain the solidarity of the kin group rather than the pursuit of certain and true knowledge. What then is meant by 'beliefs'? These beliefs, otherwise known as matauranga Maori, are best understood as 'mirror knowledge'. Mirror knowledge is the projection of the self outwards, so that all things are ultimately known through the connection to the self (Tau, 2001:136).

To add emphasis to this interpretation, Tau (2001:136-7) argues that the use of personification by Maori led to the projection of themselves onto the world which was then mirrored back again forming a closed circle of knowledge. This view appears to be supported by stories that explicitly describe a belief in the literal personification of (for example) a stone as an ancestor (Treagear 1898 retold in Orbell, 1991:2). In contradiction Best (1982:291-2) argues that Maori used personification as an allegorical 'tool' whereby the nature of something and its causality could be better understood; and when used in this sense, was a 'precursor of science.'

In support of this view, non-human whakapapa indicate that many of the beings personified as the parent/progenitor of things have embedded in their names important qualities, traits or biological characteristics of that species. Best (1982:266) gives several examples. One is Moe-tahuna (glossed as 'sandsleeper') said to be the parent/personification of the grey duck which likes to sleep in such places. But not all personifications have names that clearly convey meanings; sometimes they act as a symbolic representation of more hidden meanings (disclosed in a narrative) in which abstract ideas have been personified.

Tau (2001) further argues that the closed, mirror-like nature of matauranga is encapsulated in the expression 'I nga ra o mua' (the days that stand to the 
fore), whereby the past is seen as before or in front of one. This belief he says, implies that 'just as Mãori imposed their past onto the landscape, the landscape therefore set the boundaries for how the present could be understood and, therefore, how the future would be written.' And so 'the individual lived within a conceptual valley encircled by ancestral alps limiting any vision to the future and reducing the individual to the known. Accordingly, actions were predetermined and, thereby, society' (Tau, 2001:139).

Non-human whakapapa such as those discussed above provide an alternative view to a predetermined, closed system of belief-based knowledge by suggesting that whakapapa are not entirely predetermined and closed but were (and are) open to new knowledge and to change as circumstances (environmental and cultural) dictate. This process commenced following initial settlement by eastern Polynesian ancestors who brought with them a Polynesian cosmogonical framework which had to be revised and adapted to provide for the new biophysical and spiritual environment. For example in eastern Polynesia the supreme god is Tangaloa, while here in Aotearoa Kane (Tane) assumes that role, replacing his former association with taro, sugar cane and bamboo with that of forest trees, birds and insects. At a more basic level many new species had to be identified, named and their taxonomic patterns and relationships with all other relevant things understood before this matauranga or everyday, environmental knowledge could be assembled upon a genealogical framework. Furthermore, the existence of multiple ontologies as demonstrated in differing versions of the above whakapapa also demonstrate that this way of seeing and understanding the world is open to change and interpretation according to the narrator's experience, knowledge and/or circumstances.

Whakapapa, it is argued, therefore act as a window rather than a mirror on the world through which many meanings may be perceived, constructed, and adapted according to geographical place, environmental and social dictates. Through these windows there is flow of knowledge in both directions, including cultural beliefs as well as empirically based environmental 'data'. In such a system, knowledge creation and acquisition is non-linear; it is instead relational and reiterative. Its purpose is not to repeat the past or to facilitate progress towards some human-directed future goal (e.g. a 'grand theory of everything' as in physics; or a single phylogeny of all known organisms as in biology), but to maintain the shifting balance and harmony of the web of interrelationships (including humans) specific to that place. As these relationships change through time, so does the knowledge, because survival and sustainability of peoples whose livelihood is intimately and directly dependent on their surrounding natural resources rests upon their ability to adopt new and/ 
or adapt their existing understandings to meet new challenges.

There would therefore seem to be no reason why new knowledge concerning the changing face of the biological and physical diversity of the New Zealand landscape cannot continue to be incorporated into whakapapa. This might consist of both endogenous as well as exogenous (hybrid) knowledge. PostEuropean examples are few but include one provided by Tau (2001:136) in which European settlers (who arrived in ships on 'the great ocean of Kiwa' or Pacific ocean) are described as descendants of Kiwa and his ancestor Takaroa (Tangaroa; god of the sea). There is also anecdotal information for a whakapapa of 'Maori potatoes' (riwai or taewa) varieties of which were selected and named following their introduction by Europeans. More recently during a debate concerning genetically modified organisms, a Te Arawa kaumatua argued that pine trees should be included in whakapapa as all trees are the children of Tane; and also as an acknowledgement of their importance to modern generations of his people.

Tau (2001:144), however, suggests that particularly during the early decades of colonization 'The ability of whakapapa to include the new was hindered by rate of knowledge transfer. This means that the influx of new and unknown 'things' occurred at a rate that was beyond the ability of the existing system to incorporate.'

This problem of 'information overload' is real and not unique to Maori. Most persons alive today and over a certain age would agree with feelings of inadequacy and an inability to keep pace with new technological knowledge and skills associated with the computer age. But this should not imply that the old ways of doing things are no longer of value, or unable to adapt to the modern world.

Another barrier identified by Tau (2001) to the creation of new endogenous knowledge arising from matauranga and wananga is the traditional belief system. 'Modernity' he says, 'could only occur with the dismantling of tribal mythologies and world views' (Tau, 2001:144), and quotes other scholars who suggest that colonization can be beneficial by helping to dismantle old traditions and beliefs thereby enabling the growth of new knowledge (2001:141). But rather than following the European example of setting religious beliefs to one side (as happened during the Enlightenment) and embracing (scientific) modernity, Maori, he says, have remained committed to either the old belief system or to a new one based on Christianity - neither of which can provide explanations based on rationality. In his words, 'Matauranga Maori has failed 
because it could not explain' (Tau, 2001:144).

In a comparative analysis of world religions including that of Maori, Turner (1992: 22-25) shares this view, describing matauranga as an encapsulated cosmology that by virtue of its belief system is incompatible with modern science.

Tau (2001:142) further argues, however, that the beliefs which served Maori as 'explanatory theories' must be capable of being scientifically tested, and he advocates the Popperian approach through falsification (as opposed to verification) as the criterion for determining the reliability of a theory. But as Laudan (1983:347) points out, neither fallibility nor verification of a theory makes it less (or more) scientific. Instead, he suggests that the real test of the value or not of any theory of knowledge, including matauranga, lies in its heuristic potential, rather than whether or not it is regarded as scientific. In other words, the creation of new knowledge is not restricted to science and its methods. Instead as Laudan (1983:347) suggests, attention should be placed on a knowledge system's empirical and conceptual claims about the world and not on whether they qualify as scientific. In this regard whakapapa has much to contribute in terms of the underlying principles (e.g. relationships between all things) and values (e.g. reciprocity and respect) inherent in this construct.

Tau's final point which is made in answer to his question 'What then is the purpose of whakapapa in the modern and postmodern age?' is that 'The only purpose can be that for which it was primarily designed - as a bonding agent. Whakapapa binds and links people' (Tau, 2001:148).

Material presented here and in other papers (e.g. Roberts, 2012c) suggest that Tau may have overlooked an important aspect of matauranga and, by implication, whakapapa. This is the importance of place; and of knowledge pertaining to place as evidenced in non-human whakapapa. Tau's failure is understandable if he is, as so many do, restricting his knowledge of whakapapa to those concerning only human beings.

Some of the best examples of how matauranga (in the form of whakapapa) is open to new knowledge and/or its reinterpretation as required within a modern context come from environmental resource managers employed by iwi to respond to cultural risk assessments under the Resource Management Act 1991. Several iwi utilize the concept of whakapapa (its history, relationships, purpose etc) as a tool to test the acceptability or not of genetically modified organisms (GMO). One Ngai Tahu environmental manager interviewed in a research project (Roberts and Fairweather, 2004) concerning South Island Maori views on 
biotechnologies such as GMo's described how he used the 'whakapapa test' as a 'risk management tool' to ensure the cultural safety and integrity of his culture when faced with an application to import or release a GMo into his rohe. As he explains it: 'Knowing the whakapapa provides the framework for making decisions about the rights and wrongs of a thing. It can tell you whether it is natural or unnatural, appropriate or inappropriate' (Roberts and Fairweather, 2004:15).

Another said that:

Whakapapa provides an understanding of how the world works...if you can trace the history of your origins or that of an organism or thing, you will gain an understanding of how things came to be and what is their place in the world, i.e. it is not just about the origins of things but the correct relationships of things one to another; this is all in the whakapapa. This knowledge can be used to make culturally safe decisions about new technologies (cited in Roberts and Fairweather, 2004:19).

Importantly, this informant includes the spiritual components of whakapapa viz:

Mauri is the spiritual aspect of whakapapa; [it] acts as the guardian protecting the tapu and mana of the whakapapa of organisms (and non-living things). Mauri warns us to be careful when we attempt to interfere with whakapapa; to be respectful, to know when we have done right or wrong. [It] acts as a spiritual gatekeeper. In this role it can be interpreted as a form of indigenous 'risk management' to be applied by those skilled in these things (cited in Roberts and Fairweather, 2004:20).

A more recent and imaginative example is provided by researchers involved in a project in which they utilize whakapapa as 'a theoretical frame to analyse the complex transnational ecological linkages surrounding contemporary TB in the Pacific' (Park et al.2011). In so doing they explore the potential for employing whakapapa as social theory and as a foundation for policy critique. This bold and innovative approach provides yet another answer to Tau's question above (and to that posed by Gillett, 2009:98) namely, how exactly should we position indigenous knowledges in a discussion of policy in post-colonial society? Some of the answers to this question have been provided by Durie (2004). He supports the open nature of indigenous knowledges and their ability to undergo endogenous adaptation over time. But he goes further to argue that 
indigenous knowledges also have the capacity to contribute to the generation of new knowledge made possible only through interaction at the interface with another knowledge system (such as western science). Importantly, however, such 'interface research' needs to involve methodologies and sets of values from both systems. (This concept parallels Popper's theory of 'culture clash' as one factor contributing to the production of new knowledge [Tau, 2001:141]).

'Interface research' has also been the subject of a project called Te Hau Mihi Ata led by Prof. Linda Smith at the University of Waikato. This aims to describe and facilitate processes of knowledge exchange and innovation that occur at the nexus of differing cultural paradigms. Using a process grounded in Kaupapa Maori theory and practice that facilitates in-depth discussion between indigenous and western science knowledge holders, participants are encouraged to create a new knowledge space, resulting in transformative thinking and innovation. Outcomes are anticipated to include not only a 'hybrid' of both systems but also new, culturally grounded matauranga that contributes to the Maori development agenda and helps shape future science directions (Smith et al.2013).

\section{CONCLUSION}

The thesis of this paper is that Maori ways of knowing about the world is by means of a genealogical framework called whakapapa. Upon this framework is assembled 800-1000 years of experiential learning about their environment. This knowledge, known as matauranga, in other cultures might be referred to as natural history; as traditional ecological knowledge (TEK); or biology and ecology. But these legitimate analogies should not persuade us to call matauranga 'science' as in the western sense of that word, as its guiding philosophy and theories - its epistemology - used to explain how the world and the knowledge in it came to be are entirely different. Unlike western science, the purpose of matauranga is not an end in itself. Its 'laws', spiritual beliefs and practices (tikanga) that explain and govern the relationships between humans and their environmental siblings are values based; on respect and reciprocity, aimed at achieving harmony and balance between all things.

In addition to its epistemological function, emphasis here has also been placed on the role of whakapapa as a folk taxonomy and an ecosystem map. Various examples drawn from different environmental 'realms' or ecosystems reveal the many faceted aspects of knowledge Maori had about their world and how genealogy (whakapapa) is used to describe the perceived ontologies and relationships between things. 
A final - but most important aim of this paper - is to encourage recognition of the important contribution this values-based world-view can make to our society in many different areas including that of western scientific research. Progress towards this outcome can best be achieved through the education system by teaching matauranga along with other indigenous epistemologies alongside the history and philosophy of western science. Without this background context and understanding of the rich tapestry of knowledge in its many colors and forms, our scholars and practitioners in both matauranga and in western science will continue to struggle to make a uniquely New Zealand contribution to knowledge innovation at the interface of both cultures.

\section{ACKNOWLEDGEMENTS}

This paper is one of several on Matauranga provided by the author as a researcher for the project 'Te Hau Mihi Ata: Mātauranga Māori, Science and Biotechnology' (UOWX0701)

NOTES

1. Williams, D., Matauranga Maori and Taonga (Waitangi Tribunal, Wellington, 2001) pp.14-26.

\section{REFERENCES}

Andersen, J.C. 1907 Maori Life in Ao-tea. Christchurch: Whitcombe and Tombs.

Berlin, B. 1992 Ethnobiological classification: principles of the classification of plants and animals in traditional societies. New Jersey: Princeton University Press.

Best, E. 1902 'Food Products of Tuhoeland: being Notes on the Food-supplies of Non-agricultural Tribes of the Natives of New Zealand; together with some Account of various Customs, Superstitions, \&c., pertaining to Foods'. Transactions and Proceedings of the Royal Society of New Zealand, 35:45-109.

Best, E. 1908 'Maori forest Lore'. Transactions of New Zealand Institute 41: 231-285.

Best, E. 1976 [1925]'Maori Agriculture'. Dominion Museum Bulletin 9. Wellington: A.R. Shearer. Government Printer.

Best, E. 1977 [1925] 'Whanui, Rongo-maui and Pani', in Tuhoe, The Children of the Mist: a sketch of the origin, history, myths and beliefs of the Tuhoe tribe of 
the Maori of New Zealand, with some account of other early tribes of the Bay of Plenty district (3rd ed). Wellington: Published for the Polynesian Society by A.H. \& A.W. Reed.

Best, E. 1982 'Maori Religion and Mythology: being an account of the cosmogony, anthropogeny, religious beliefs and rites, magic and folk lore of the Maori folk of New Zealand. Part II'. Dominion Museum Bulletin 11. Wellington: Government Printer.

Best, E. 1995 Maori Religion and Mythology Part I. Wellington: Museum of New Zealand/Te Papa Tongarewa. (First published as Dominion Museum Bulletin 10, 1924.)

Bulmer, R. 1970 'Which came first: the chicken or the egg-head?', in C. Levi-Strauss, J. Pouillon, and P. Maranda (eds). Echanges et communications: melanges offerts a Claude Levi-Strauss a l'occasion de son 6oeme anniversaire. The Hague: Mouton:1069-1091.

Bulmer, R. 1974 'Folk biology in the New Guinea Highlands', Social Science Information, 13:9-28.

Diamond, J. 1972 Avifauna of the Eastern New Guinea Highlands. Cambridge, Mass: Nuttal Ornithological Club.

Doak, W. 2003 A Photographic Guide to the Sea Fishes of New Zealand. Auckland: New Holland Publishers.

Durie, M. 2004 'Exploring the interface between science and indigenous knowledge'. Paper presented at the 5 th APEC Research \& Development leaders Forum, March 11th, Christchurch.

Gillett, G. 2009 'Indigenous knowledges: circumspection, metaphysics, and scientific ontologies', Sites: New Series, 6(1): 97-115.

Howe, K.R. 2008 Vaka Moana: voyages of the ancestors, Auckland: Bateman.

Haami B. and Roberts, M. 2002 'Whakapapa (genealogy) as taxonomy', International Social Science Journal 173: 443-452.

Handy, E.S.C. and Handy, E.G. 1991 Native Planters in old Hawaii: their life, lore and environment, Honolulu, Hawaii: Bishop Museum Press. 
Howitt, R. and Suchet-Pearson, S. 2006 'Rethinking the building blocks: ontological pluralism and the idea of "management", Geografiska Annaler, 88B (3):323-335.

Levi-Strauss, C. 1966 The Savage Mind, London: Weidenfeld and Nicolson.

Mead, H.M. 1986 Te Toi Whakairo: the art of Maori carving, Birkenhead, Auckland: Reed Publishing (NZ) Ltd.

Miller, D. 1971 Common Insects in New Zealand, Wellington: A H and A W Reed.

Orbell, M. 1991 Hawaiki: a new approach to Maori tradition, Christchurch: Canterbury University Press.

Orbell, M. 1995 The Illustrated Encyclopedia of Maori Myth and Legend, Christchurch: Canterbury University Press.

Park, J., Littleton, J., Chambers, A. and Chambers, K. 2011 'Whakapapa in anthropological research on tuberculosis in the Pacific', Sites: New Series, 8(2): 6-31.

Reed, A.W. 1963 Treasury of Maori Folklore, Wellington: A.H. and A.W. Reed.

Riley, M. 1997 Maori Healing and Herbal, Paraparaumu: Viking Sevenseas N.Z. Ltd.

Roberts, M. 2012 (a) 'Genealogy of the sacred - Maori beliefs concerning lizards', in Pungetti G., Oviedo, G and Hooke, D (eds) Sacred Species and Sites, Cambridge: Cambridge University Press: 249-264.

Roberts, M. 2012 (b) 'Mind maps of the Māori', GeoJournal, 77(6):741-751.

Roberts, M. 2012 (c) 'Revisiting the natural world of the Maori', in Keenan, D. (ed) Huia Histories of Maori. Wellington: Huia:33-56.

Roberts R.M., Haami B., Benton R., Satterfield T., Finucane M.L., Henare M. and Henare, M. 2004 'Whakapapa as a Maori mental construct: some implications for the debate over genetic modification of organisms', The Contemporary Pacific, 16(1):1-28.

Roberts, M. and Fairweather, J.R. 2004 South Island Maori perceptions of biotechnology. Research report No.268. Canterbury: Agribusiness and Economics research Unit, Lincoln University. 
Roberts, M. and Wills, P. 1998 'Understanding Maori epistemology -a scientific perspective', in H. Wautischer (ed) Tribal Epistemologies: Essays in the Philosophy of Anthropology. England: Ashgate Publishers Ltd: 43-77.

Roberts, M. 1996 'Indigenous knowledge and Western Science: perspectives from the Pacific', 59-75 in Science and Technology, Education and Ethnicity: an Aotearoa/New Zealand perspective. Proceedings of a conference held in Wellington, May 7-8 1996. Published by

Royal Society of New Zealand, 1996 conference. Misc. series 50.

Salmond, A. 1991 Two Worlds: First Meetings Between Maori and Europeans 16421772. Auckland: Viking.

Salmond, A., and Salmond, A. 2010 'Artefacts of encounter', Interdisciplinary Science Reviews, 35(3-4):302-317.

Simpson, P. 2000 Dancing Leaves: The Story of New Zealand's Cabbage Tree. Ti Kouka. Canterbury: Canterbury University Press.

Smith, L., Hemi, M., Hudson, M., Roberts, M., Tiakiwai, S., and Baker, M. 2013 'Dialogue at the Cultural Interface'. A report for Te Hau Mihi Ata: Matauranga Maori, Science and Biotechnology. Hamilton: University of Waikato.

Tau, Te M. 1999 'Matauranga Maori as an epistemology', Te Pouhere Korero, $1(1): 10-23$.

Tau, Te M.2001 'The death of knowledge', New Zealand Journal of History, 35 (2):131-152.

Walter, R. and Moeka'a R. (eds) 2000 'History and traditions of Rarotonga by Te Ariki-tara-are', Polynesian Society Memoir, 51:125-127 (Modern English Translation).

White, J. 1887 Ancient History of the Maori, His Mythology and Traditions: HoroUta or Taki-Tumu Migration. Vol I. Wellington: George Didsbury/Government Printer.

Williams, D. 2001 'Matauranga Maori and Taonga. Wellington: Waitangi Tribunal:14-26. 